\title{
Ameliorative effects of potassium nutrition on yield and fiber quality characteristics of cotton (Gossypium hirsutum L.) under $\mathrm{NaCl}$ stress
}

\author{
Muhammad Ashraf ${ }^{*}$, Sher Muhammad Shahzad ${ }^{1}$, Muhammad Imtiaz, \\ Muhammad Shahid Rizwan ${ }^{2}$ and Muhammad Mahzar Iqbal ${ }^{3}$ \\ ${ }^{1}$ Department of Soil and Environmental Sciences, University College of Agriculture, University of Sargodha, Sargodha, Pakistan \\ ${ }^{2}$ College of Resources and Environment, Huazhong Agricultural University, Wuhan 430070, PR China \\ ${ }^{3}$ Soil and Water Testing laboratory, Chiniot
}

\begin{abstract}
Cotton (Gossypium hirsutum L.) being moderately tolerant to salinity has been extensively grown in arid and semiarid regions where soil salinization is a major threat to plant growth and soil productivity. Excess salts in the growth medium may interfere with growth processes of cotton, leading to a severe decline in yield and fiber quality characteristics. Adequate mineral nutrient status of plants can provide an important strategy to improve plant tolerance to salinity. A pot experiment was planned to evaluate the ameliorative effects of additional potassium $(K)$ applied at 50 and $100 \mathrm{mg} \mathrm{K}_{2} \mathrm{O} \mathrm{kg} \mathrm{g}^{-1}$ soil as potassium sulfate against $\mathrm{NaCl}$ stress of 100 and $180 \mathrm{mM}$ in cotton. The experiment was conducted according to completely randomized design with five replications. $\mathrm{NaCl}$ caused a significant $(P \leq 0.05)$ increase in shoot sodium $\left(\mathrm{Na}^{+}\right)$and chloride $\left(\mathrm{Cl}^{-}\right)$with a corresponding decrease in shoot $\mathrm{K}^{+}$, $\mathrm{K}^{+}: \mathrm{Na}^{+}$ratio, calcium $\left(\mathrm{Ca}^{2+}\right)$ and magnesium $\left(\mathrm{Mg}^{2+}\right)$. Plant growth, yield and fiber quality characteristics were also declined significantly by increasing external $\mathrm{NaCl}$ concentration. Additional $\mathrm{K}$ reduced shoot $\mathrm{Na}^{+}$while increased $\mathrm{K}^{+}, \mathrm{K}^{+}: \mathrm{Na}^{+}$ratio, $\mathrm{Ca}^{2+}$ and $\mathrm{Mg}^{2+}$ with the consequent improvement in plant growth, lint yield and yield attributes as well as fiber quality characteristics at both levels of $\mathrm{NaCl}$. Results revealed that $\mathrm{K}$ nutrition improved shoot $\mathrm{K}^{+}: \mathrm{Na}^{+}$ratio by 116 and $246 \%$ at $\mathrm{NaCl}_{100}$ while 188 and $294 \%$ at $\mathrm{NaCl}_{180}$ with $\mathrm{K}_{50}$ and $\mathrm{K}_{100}$, respectively as compared to $\mathrm{NaCl}$ treated plants without additional K. Likewise, lint yield was improved by 38.27 and $60.49 \%$ at $\mathrm{NaCl}_{100}$ while 75.12 and $136 \%$ at $\mathrm{NaCl}_{180}$ with $\mathrm{K}_{50}$ and $\mathrm{K}_{100}$, respectively compared to $\mathrm{NaCl}$ stressed plants without additional $\mathrm{K}$. Ameliorative effects of $\mathrm{K}$ against $\mathrm{NaCl}$ stress were relatively more prominent at higher $\mathrm{K}$ application at both $\mathrm{NaCl}$ levels. In conclusion, $\mathrm{K}$-induced decrease in $\mathrm{Na}^{+}$, increase in $\mathrm{Ca}^{2+}, \mathrm{K}^{+}, \mathrm{K}^{+}: \mathrm{Na}^{+}$ratio, relative water content and membrane stability index provide protective mechanisms against $\mathrm{NaCl}$ stress. However, the results need to be confirmed under field conditions and the economic feasibility should be worked out.
\end{abstract}

Keywords: MSI; Plant growth; Plant tolerance; Potassium; RWC; Salinity; Sodium

\section{Introduction}

Soil salinity is one of the most damaging environmental factors which inhibit plant growth, yield and quality in wide variety plant species, particularly in arid and semiarid regions of the world where evapotranspiration is greater than precipitation. Globally, about $20 \%$ of the cultivated land and greater than half of the irrigated land are currently affected by salts to varying degree (Arzani, 2008). Furthermore, there is an annual increase of about $10 \%$ in soil salinization, and it is expected that more than $50 \%$ of the world arable land will be affected with salts by the year 2050 (Jamil et al., 2011). The build-up of salt ions, particularly $\mathrm{Na}^{+}$and $\mathrm{Cl}^{-}$in the rooting medium and their subsequent accumulation by plant can affect plant growth and metabolism through ion toxicity, nutrient imbalances, reduction in water uptake and alteration in enzyme activities (Ashraf et al., 2015a). In saline environment, plants usually face certain unfavorable conditions such as low soil water potential, $\mathrm{Na}^{+}$and $\mathrm{Cl}^{-}$ toxicity, $\mathrm{Ca}^{2+}$ and $\mathrm{K}^{+}$deficiency, altered metabolism, membrane destabilization, reduction in cell division and expansion, all of these ultimately lead to marked reduction in plant growth and yield (Ashraf et al., 2012). In saline environment, different growth and developmental processes including seed germination, seedling establishment, vegetative development, flowering, fruit formation and quality are adversely influenced by increasing salinity (Sairam and Tyagi, 2004).

Cotton (Gossypium hirsutum L.) is moderately tolerant to salinity with a threshold level of $7.7 \mathrm{dS} \mathrm{m}^{-1}$ electrical conductivity (EC) beyond which its yield reduces by about $5.2 \%$ per unit $\mathrm{dS} \mathrm{m}^{-1}$ increase in EC (Maas, 1986). Reduction in cotton growth and yield in saline environment is mainly due to reduced germination and subsequent poor plant establishment (Ashraf, 2002). Jafri and Ahmad (1994)

*Email: mashraf_1972@yahoo.com 
reported that long-term exposure of cotton plants to salinity stress often caused deferred fruit initiation, reduction in fruit development, enhanced fruit shed and delayed maturity with the subsequent reduction in boll number, boll weight, seed cotton yield, lint percentage, staple length, and fiber strength. Chen et al. (2010) found that cotton yield was reduced by 10 , 25 and $50 \%$ at 10, 12 and $16 \mathrm{dS} \mathrm{m}^{-1}$ EC, respectively. Khorsandi and Anagholi (2009) also reported that salinity stress delayed and reduced germination and seedling emergence, decreased vegetative and reproductive growth, and ultimately led to a marked reduction in cotton yield and fiber quality characteristics at moderate to high levels of soil salinization. In saline environment, excess $\mathrm{Na}^{+}$or deficiency of $\mathrm{K}^{+}$, particularly at reproductive stage can damage the structure of fruit-bearing organs, and decrease the seed cotton yield and fiber quality (Zhang et al., 2014). Relative water content (RWC) and membrane stability index (MSI) are usually greatly influenced by salinity, and considered as important criteria for evaluating the plant's capability to endure salinity stress (Win et al., 2011; Ghogdi et al., 2012). Adequate plant nutrition can provide an effective strategy for improving plant growth and development in saline environment (Waraich et al., 2011, Ashraf et al., 2015b). Among the mineral nutrients, potassium (K) uptake and accumulation by plants is particularly influenced by high salinity, particularly $\mathrm{Na}^{+}$in the growth medium depending upon many plant and soil factors (Shirazi et al., 2005). In saline environment, $\mathrm{Na}^{+}$has antagonistic effects with $\mathrm{K}^{+}$, and therefore plant's capabilities to adapt saline environment may be associated with plant's selectivity to prefer $\mathrm{K}^{+}$over $\mathrm{Na}^{+}$. This hypothesis provides the base for the protective role of $\mathrm{K}$ against salinity stress. (Ashraf et al., 2010; Ashraf et al., 2012; Ashraf et al., 2015a; 2015b). Potassium generally makes an important contribution to osmotic adjustment in plants that is vital for water balance within the plant body which otherwise severely disturbed under saline conditions (Marschner, 1995; Mengel and Kirkby, 2001). Potassium also helps to improve $\mathrm{Ca}^{2+}$ accumulation within plants which improves membrane structure and reduces boll abscission. Cotton is considered to be relatively more sensitive to $\mathrm{K}$ deficiency, often exhibits the deficiency symptoms on soils not usually regarded as $\mathrm{K}$ deficient (Cassman et al., 1989). On the other hand, saline environment is mostly characterized by $\mathrm{K}$ deficiency. Accordingly, a pot experiment was planned to evaluate the effects of $\mathrm{K}$ nutrition for improving growth, yield and fiber quality of cotton under $\mathrm{NaCl}$ stress.

\section{Materials and Methods}

\section{Soil characteristics}

A pot experiment with cotton was carried out to evaluate the protective role of $\mathrm{K}$ for reversing the damaging effects of $\mathrm{NaCl}$ on yield and yield attributes as well as fiber quality characteristics. Soil used in this study was sandy clay loamy having, $\mathrm{pH} 7.9$, EC $1.3 \mathrm{dS} \mathrm{m}^{-1}$, sodium adsorption ratio (SAR) $6.4\left(\mathrm{mmol} \mathrm{L}^{-1}\right)^{1 / 2}$, organic matter $0.71 \%$, nitrogen (N) $337 \mathrm{mg} \mathrm{kg}^{-1}$, phosphorus (P) $4.3 \mathrm{mg}$ $\mathrm{kg}^{-1}, \mathrm{~K} 122 \mathrm{mg} \mathrm{kg}^{-1}$ and saturation percentage $38.4 \%$.

\section{Plant growth}

Cotton seeds of cultivar BT-Super 101 were sown in earthen glazed pots filled with $12 \mathrm{~kg}$ soil, collected from the top $20 \mathrm{~cm}$ depth of a cultivated field. After germination, two healthy plants were maintained in each pot. The plant protection measures were adopted uniformly for all treatments. $\mathrm{N}$ at $100 \mathrm{mg}$ as urea, $\mathrm{P}$ at $40 \mathrm{mg} \mathrm{P}_{2} \mathrm{O}_{5}$ as single super phosphate and $\mathrm{K}$ at $40 \mathrm{mg} \mathrm{K}_{2} \mathrm{O}$ as potassium sulfate $\mathrm{kg}^{-1}$ soil were applied. Whole $\mathrm{P}, \mathrm{K}$ and one third $\mathrm{N}$ were applied at the time of sowing while remaining $\mathrm{N}$ was added in two splits, at flowering and boll formation stages. Harvesting was done in two phase, one plant from each pot was harvested 50 days after treatment completion while $2^{\text {nd }}$ plant was allowed to mature.

\section{Treatment plan}

Seven treatments, $\mathrm{T}_{1}$ Control (no $\mathrm{NaCl}$, no additional $\mathrm{K}), \mathrm{T}_{2} \mathrm{NaCl}_{100}: 100 \mathrm{mM} \mathrm{NaCl}, \mathrm{T}_{3} \mathrm{NaCl}_{100}+\mathrm{K}_{50}: 100 \mathrm{mM}$ $\mathrm{NaCl}+50 \mathrm{mg} \mathrm{K} \mathrm{K} \mathrm{kg}^{-1}$ soil, $\mathrm{T}_{4} \mathrm{NaCl}_{100}+\mathrm{K}_{100}$ : $100 \mathrm{mM}$ $\mathrm{NaCl}+100 \mathrm{mg} \mathrm{K}_{2} \mathrm{O} \mathrm{kg}$ soil, $\mathrm{T}_{5} \mathrm{NaCl}_{180}: 180 \mathrm{mM} \mathrm{NaCl}, \mathrm{T}_{6}$ $\mathrm{NaCl}_{180}+\mathrm{K}_{50}$ : $180 \mathrm{mM} \mathrm{NaCl}+50 \mathrm{mg} \mathrm{K}_{2} \mathrm{O} \mathrm{kg}{ }^{-1}$ soil, $\mathrm{T}_{7}$ $\mathrm{NaCl}_{180}+\mathrm{K}_{100}$ : $180 \mathrm{mM} \mathrm{NaCl}+100 \mathrm{mg} \mathrm{K}_{2} \mathrm{O} \mathrm{kg}{ }^{-1}$ soil, were arranged according to completely randomized design with five replications. Additional $\mathrm{K}$ as potassium sulfate was added according to treatment plan at the time of planting. At $10^{\text {th }}$ day after seedling emergence, the required amount $\mathrm{NaCl}$ salt was dissolved in water and drenched into respective pots gradually within 48 hours.

\section{Relative water content (RWC)}

Forty two days after treatment completion, $3^{\text {rd }}$ leaf from the shoot tip of both plants were sampled and weighed immediately to record fresh weight $(\mathrm{FW})$. For recording turgid weight (TW), the leaves were dipped in distilled water for about $4 \mathrm{~h}$ and weighed after removing the water from the leaf surface with tissue paper. The leaves were then oven dried at $70^{\circ} \mathrm{C}$ for $48 \mathrm{~h}$ to record oven-dried weight (ODW). RWC was determined according to Yamasaki and Dillenburg (1999):

$$
\mathrm{RWC}(\%)=[(\mathrm{FW}-\mathrm{ODW}) /(\mathrm{TW}-\mathrm{ODW}] \times 100
$$

\section{Membrane stability index (MSI)}

Fourth leaf from the shoot tip of both plants were collected 42 days after treatment completion. The leaves were cut into $1.0 \mathrm{~cm}$ diameter pieces and put in test tubes having $10 \mathrm{~mL}$ distilled water in two sets. One set of test 
tubes were kept in water at $40^{\circ} \mathrm{C}$ for $30 \mathrm{~min}$ and the $\mathrm{EC}$ of water having leaf sample was measured $\left(C_{1}\right)$. The second set of test tubes were incubated at $100^{\circ} \mathrm{C}$ in boiling water for $15 \mathrm{~min}$ and their $\mathrm{EC}$ was measured $\left(\mathrm{C}_{2}\right)$. MSI was calculated according to Sairam et al. (1997):

$$
\operatorname{MSI}(\%)=\left[1-\mathrm{C}_{1} / \mathrm{C}_{2}\right] \times 100
$$

\section{Ionic characteristics}

Fifty days after treatment completion, one plant from each pot was harvested and used to determine $\mathrm{Na}^{+}, \mathrm{Cl}^{-}, \mathrm{K}^{+}$, $\mathrm{Ca}^{2+}$ and $\mathrm{Mg}^{2+}$ concentrations in plant shoots. After thorough washing with distilled water, plant samples were first airdried and then oven dried at $70^{\circ} \mathrm{C}$ for $48 \mathrm{~h}$. After grinding, $0.5 \mathrm{~g}$ portion of ground shoot samples was digested in $10 \mathrm{~mL}$ mixture of concentrated nitric acid and perchloric acid (2:1, $\mathrm{v} / \mathrm{v})$ at $250^{\circ} \mathrm{C}$. Flame photometer was used to estimate shoot $\mathrm{K}^{+}$and $\mathrm{Na}^{+}$, atomic absorption spectroscopy for $\mathrm{Ca}^{2+}$ and $\mathrm{Mg}^{2+}$ while chloride analyzer for $\mathrm{Cl}^{-}$.

\section{Fiber quality characteristics}

Ginning out turn was recorded as ratio between weight of the lint and weight of the seed cotton. Fiber length was measured by Fibrograph (ASTM, 1994a), fiber fineness by Micronaire Tester (ASTM, 1994b) and fiber strength by Pressley Fiber Bundle Tester (ASTM, 1994c). levels of $\mathrm{NaCl}$ and additional $\mathrm{K}$ in the growth medium (Table 1). $\mathrm{NaCl}$ development in soil caused a marked increase in shoot $\mathrm{Na}^{+}$and $\mathrm{Cl}^{-}$while decrease in shoot $\mathrm{Ca}^{2+}$, $\mathrm{Mg}^{2+}, \mathrm{K}^{+}$and $\mathrm{K}^{+}$: $\mathrm{Na}^{+}$ratio as compared to control. Addition of $\mathrm{K}$ in both levels reversed the deleterious effects of $\mathrm{NaCl}$, with greater amelioration at higher level of additional $\mathrm{K}$ at both $\mathrm{NaCl}$ concentrations. Shoot $\mathrm{Na}^{+}$ concentrations were decreased by 26.90 and $42.69 \%$ at $\mathrm{NaCl}_{100}$ while 38.97 and $51.02 \%$ at $\mathrm{NaCl}_{180}$, shoot $\mathrm{Cl}^{-} 12.86$ and $24.37 \%$ at $\mathrm{NaCl}_{100}$ while 13.09 and $21.70 \%$ at $\mathrm{NaCl}_{180}$ with $\mathrm{K}_{50}$ and $\mathrm{K}_{100}$, respectively compared to salt treated plants without additional $\mathrm{K}$. In contrast, shoot $\mathrm{K}^{+}$was increased by 57.98 and $94.68 \%$ at $\mathrm{NaCl}_{100}$ while 77.27 and $92.72 \%$ at $\mathrm{NaCl}_{180}, \mathrm{~K}^{+}: \mathrm{Na}^{+}$ratio 116 and $246 \%$ at $\mathrm{NaCl}_{100}$ while 188 and $294 \%$ at $\mathrm{NaCl}_{180}, \mathrm{Ca}^{2+} 23.96$ and $47.92 \%$ at $\mathrm{NaCl}_{100}$ while 37.24 and $64.22 \%$ at $\mathrm{NaCl}_{180}, \mathrm{Mg}^{2+} 15.29$ and $22.35 \%$ at $\mathrm{NaCl}_{100}$ while 42.10 and $59.21 \%$ at $\mathrm{NaCl}_{180}$ with $\mathrm{K}_{50}$ and $\mathrm{K}_{100}$, respectively compared to $\mathrm{NaCl}$ treated plants without additional $\mathrm{K}$.

\section{Relative water content and membrane stability index}

Maximum RWC were found in control which were declined by $16.78 \%$ at $\mathrm{NaCl}_{100}$ and $28.02 \%$ at $\mathrm{NaCl}_{180}$. Additional $\mathrm{K}$ improved RWC by 6.41 and $15.86 \%$ at

Table 1: Shoot ionic concentration (\%) of cotton (Gossypium hirsutum L.) grown under NaCl stress by supplying K

\begin{tabular}{lcccccc}
\hline Treatments & $\mathbf{K}^{+}$ & $\mathbf{N a}^{+}$ & $\mathbf{K}^{+}: \mathbf{N a}^{+}$ratio & $\mathbf{C l}^{-}$ & $\mathbf{C a}^{\mathbf{2 +}}$ & $\mathbf{M g}^{\mathbf{2 +}}$ \\
\hline Control & $2.50 \mathrm{bc}$ & $1.33 \mathrm{e}$ & $1.886 \mathrm{a}$ & $1.83 \mathrm{f}$ & $2.80 \mathrm{a}$ & $0.214 \mathrm{ab}$ \\
$\mathrm{NaCl}_{100}$ & $1.88 \mathrm{~d}$ & $3.42 \mathrm{~b}$ & $0.554 \mathrm{~cd}$ & $3.41 \mathrm{~cd}$ & $1.88 \mathrm{~cd}$ & $0.170 \mathrm{bc}$ \\
$\mathrm{NaCl}_{100}+\mathrm{K}_{50}$ & $2.97 \mathrm{~b}$ & $2.50 \mathrm{~cd}$ & $1.196 \mathrm{~b}$ & $2.97 \mathrm{de}$ & $2.33 \mathrm{abc}$ & $0.196 \mathrm{abc}$ \\
$\mathrm{NaCl}_{100}+\mathrm{K}_{100}$ & $3.66 \mathrm{a}$ & $1.96 \mathrm{de}$ & $1.918 \mathrm{a}$ & $2.58 \mathrm{e}$ & $2.78 \mathrm{a}$ & $0.208 \mathrm{ab}$ \\
$\mathrm{NaCl}_{180}$ & $1.10 \mathrm{e}$ & $4.90 \mathrm{a}$ & $0.226 \mathrm{~d}$ & $5.04 \mathrm{a}$ & $1.64 \mathrm{~d}$ & $0.152 \mathrm{c}$ \\
$\mathrm{NaCl}_{180}+\mathrm{K}_{50}$ & $1.95 \mathrm{~d}$ & $2.99 \mathrm{bc}$ & $0.652 \mathrm{c}$ & $4.38 \mathrm{~b}$ & $2.25 \mathrm{bc}$ & $0.216 \mathrm{ab}$ \\
$\mathrm{NaCl}_{180}+\mathrm{K}_{100}$ & $2.12 \mathrm{~cd}$ & $2.40 \mathrm{~cd}$ & $0.890 \mathrm{bc}$ & $3.95 \mathrm{bc}$ & $2.69 \mathrm{ab}$ & $0.242 \mathrm{a}$ \\
\hline
\end{tabular}

Values in a column followed by the same letter are not significantly different at $P \leq 0.05$. Control: no $\mathrm{NaCl}$, no additional $\mathrm{K}, \mathrm{NaCl}{ }_{100}$ : $100 \mathrm{mM} \mathrm{NaCl}, \mathrm{NaCl}_{100}+\mathrm{K}_{50}: 100 \mathrm{mM} \mathrm{NaCl}+50 \mathrm{mg} \mathrm{K}_{2} \mathrm{O} \mathrm{kg}$ soil, $\mathrm{NaCl}_{100}+\mathrm{K}_{100}: 100 \mathrm{mM} \mathrm{NaCl}+100 \mathrm{mg} \mathrm{K}_{2} \mathrm{O} \mathrm{kg}^{-1}$ soil, NaCl $\mathrm{Na}_{180}: 180$ $\mathrm{mM} \mathrm{NaCl}, \mathrm{NaCl}_{180}+\mathrm{K}_{50}: 180 \mathrm{mM} \mathrm{NaCl}+50 \mathrm{mg} \mathrm{K}_{2} \mathrm{O} \mathrm{kg}^{-1}$ soil, $\mathrm{NaCl}_{180}+\mathrm{K}_{100}: 180 \mathrm{mM} \mathrm{NaCl}+100 \mathrm{mg} \mathrm{K}_{2} \mathrm{O} \mathrm{kg}^{-1}$ soil

\section{Statistical analysis}

Data were statistically analyzed according to Mstat-C. The effects of treatments were compared using analysis of variance. Least significant difference test (LSD, $\mathrm{P} \leq 0.05$ ) was used to compare the difference between means.

\section{Results}

\section{Shoot ionic concentration}

Shoot ionic concentrations including $\mathrm{Na}^{+}, \mathrm{Cl}^{-}, \mathrm{K}^{+}, \mathrm{Ca}^{2+}$ and $\mathrm{Mg}^{2+}$ were significantly $(\mathrm{P} \leq 0.05)$ affected by different
$\mathrm{NaCl}_{100}$ while 11.19 and $22.16 \%$ at $\mathrm{NaCl}_{180}$ by $\mathrm{K}_{50}$ and $\mathrm{K}_{100}$, respectively compared to $\mathrm{NaCl}$ treated plants without additional K (Fig. 1). MSI was decreased by 13.29 and $29.78 \%$ at $\mathrm{NaCl}_{100}$ and $\mathrm{NaCl}_{180}$, respectively compared to control. $\mathrm{K}$ nutrition interfered with $\mathrm{Na}^{+}$, and improved MSI at both levels of $\mathrm{NaCl}$ and added $\mathrm{K}$. However, ameliorative effect of additional $\mathrm{K}$ was relatively more prominent at higher additional $\mathrm{K}$ compared to lower level at both $\mathrm{NaCl}$ concentrations in the growth medium (Fig. 2). There was a significant positive correlation of shoot $\mathrm{K}^{+}$with $\mathrm{RWC}\left(\mathrm{R}^{2}=0.659\right.$, Fig. 3) MSI ( $\mathrm{R}^{2}=0.684$, Fig. 4). 


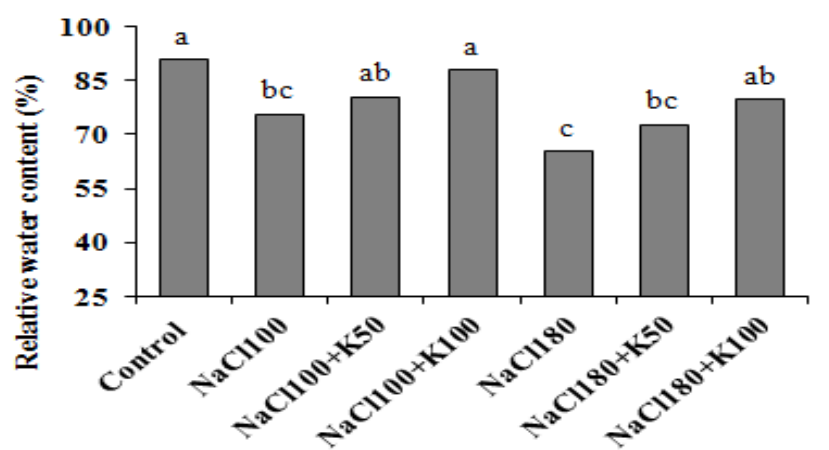

Figure 1: Relative water content of cotton (Gossypium hirsutum L.) grown under $\mathrm{NaCl}$ stress by supplying $K$. Values followed by the same letter are not significantly different at $\boldsymbol{p} \leq \mathbf{0 . 0 5}$.

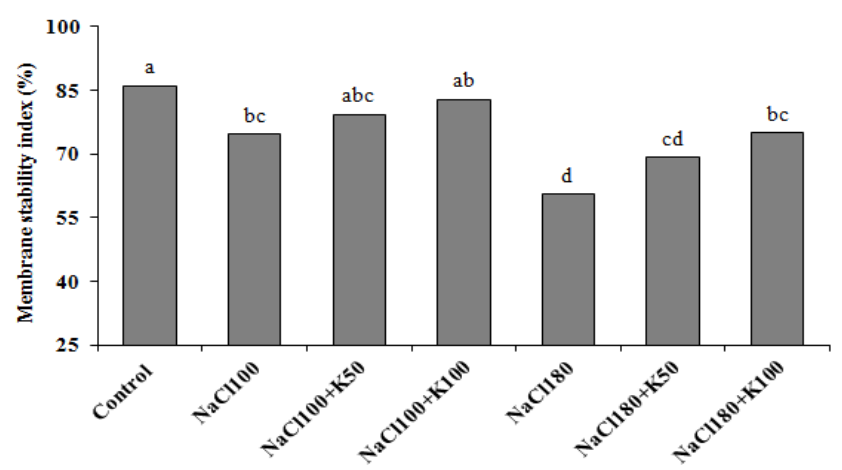

Figure 2: Membrane stability index of cotton (Gossypium hirsutum $\mathrm{L}$.) grown under $\mathrm{NaCl}$ stress by supplying $K$. Values followed by the same letter are not significantly different at $\boldsymbol{P} \leq \mathbf{0 . 0 5}$.

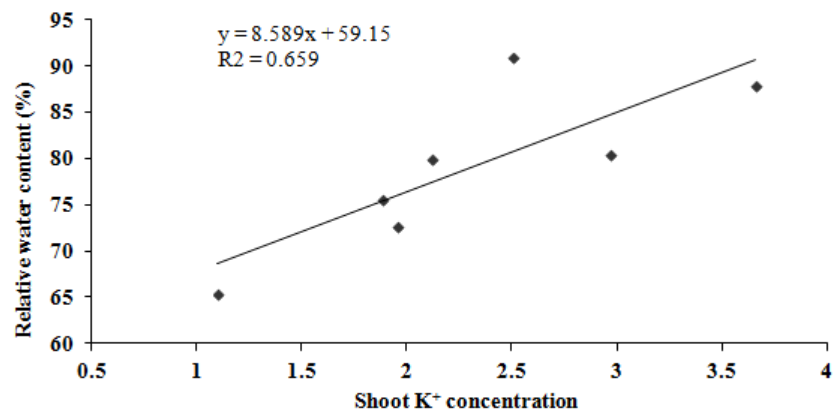

Figure 3: Correlation between shoot $\mathrm{K}^{+}$concentration and relative water content in cotton grown under $\mathrm{NaCl}$ stress by supplying $\mathrm{K}$

\section{Growth and yield characteristics}

Plant growth and yield characteristics in term of plant height, boll number plant $^{-1}$, boll diameter, seed cotton weight boll ${ }^{-1}$, seed cotton weight plant $^{-1}$, seed weight plant ${ }^{-1}$ and lint yield plant $^{-1}$ were significantly $(\mathrm{P} \leq 0.05)$ influenced by $\mathrm{NaCl}$ and additional $\mathrm{K}$ (Table 2). At $\mathrm{NaCl}_{100}$, plant height was decreased by $26.36 \%$ compared to control which was improved by 13.03 and $22.32 \%$ with $\mathrm{K}_{50}$ and $\mathrm{K}_{100}$, respectively compared to $\mathrm{NaCl}_{100}$ without additional K. At $\mathrm{NaCl}_{180}$, plant height was decreased by $40.28 \%$ compared to control.

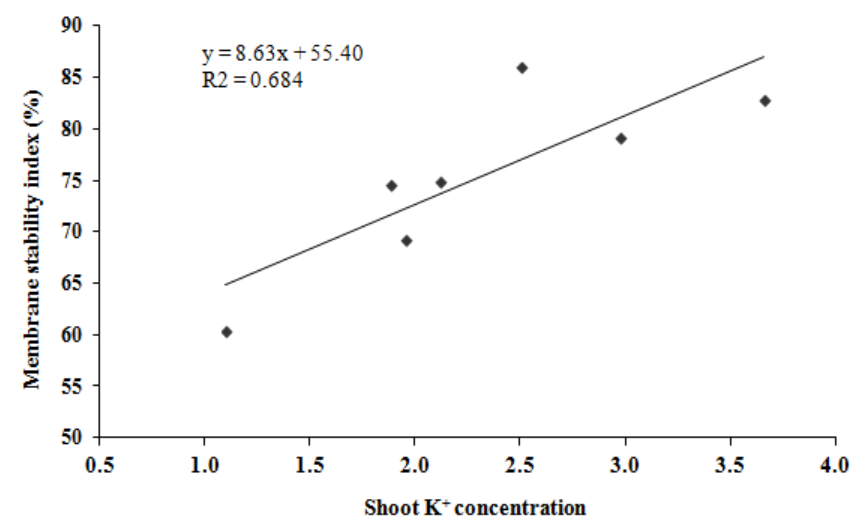

Fig. 4: Correlation between shoot $\mathrm{K}^{+}$concentration and membrane stability index in cotton grown under $\mathrm{NaCl}$ stress by supplying $\mathrm{K}$

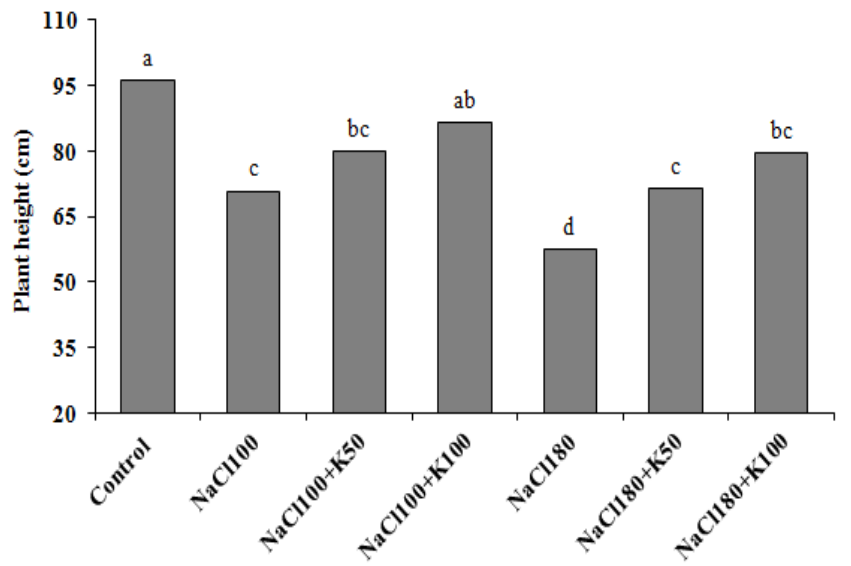

Fig. 5: Plant height of cotton (Gossypium hirsutum L.) grown under $\mathrm{NaCl}$ stress by supplying $\mathrm{K}$

However, $\mathrm{K}$ nutrition reversed the deleterious effects of $\mathrm{NaCl}$ and improved plant height by 24.56 and $38.36 \%$ with $\mathrm{K}_{50}$ and $\mathrm{K}_{100}$, respectively compared to $\mathrm{NaCl}_{180}$ plants without additional $\mathrm{K}$ (Fig. 5). Boll number per plant was decreased by 35.21 and $53.52 \%$ by $\mathrm{NaCl}_{100}$ and $\mathrm{NaCl}_{180}$, respectively compared to control. Additional $\mathrm{K}$ improved boll number plant ${ }^{-1}$ by 21.74 and $30.43 \%$ at $\mathrm{NaCl}_{100}$ while 53.52 and $60.60 \%$ at $\mathrm{NaCl}_{180}$ with $\mathrm{K}_{50}$ and $\mathrm{K}_{100}$, respectively compared to $\mathrm{NaCl}$ treated plant without $\mathrm{K}$. Boll diameter and seed cotton weight per boll were markedly reduced by $\mathrm{NaCl}_{100}$ and $\mathrm{NaCl}_{180}$ compared to control. Additional $\mathrm{K}$ 
Table 2: Yield and yield characteristics of cotton (Gossypium hirsutum L.) grown under NaCl stress by supplying $\mathrm{K}$

\begin{tabular}{|c|c|c|c|c|c|c|}
\hline Treatment & $\begin{array}{c}\text { Boll number } \\
\text { plant }^{-1}\end{array}$ & $\begin{array}{c}\text { Boll diameter } \\
(\mathrm{cm})\end{array}$ & $\begin{array}{c}\text { Seed cotton } \\
\text { weight boll }^{-1} \\
(\mathrm{~g})\end{array}$ & $\begin{array}{l}\text { Seed cotton } \\
\text { weight plant }^{-1} \\
\text { (g) }\end{array}$ & $\begin{array}{c}\text { Seed weight } \\
\text { plant }^{-1}(\mathrm{~g})\end{array}$ & $\begin{array}{l}\text { Lint yield } \\
\text { plant }^{-1}(\mathrm{~g})\end{array}$ \\
\hline Control & $14.20 \mathrm{a}$ & $2.73 a$ & $2.51 \mathrm{a}$ & $35.79 \mathrm{a}$ & $24.28 \mathrm{a}$ & $11.51 \mathrm{a}$ \\
\hline $\mathrm{NaCl}_{100}$ & $9.20 \mathrm{~cd}$ & $2.04 \mathrm{bc}$ & $2.04 b c$ & $18.80 \mathrm{c}$ & $11.51 \mathrm{~cd}$ & $7.29 b c$ \\
\hline $\mathrm{NaCl}_{100}+\mathrm{K}_{50}$ & $11.20 \mathrm{bc}$ & $2.23 b$ & $2.22 \mathrm{bc}$ & $24.38 b c$ & $14.36 \mathrm{bc}$ & $10.08 \mathrm{a}$ \\
\hline $\mathrm{NaCl}_{100}+\mathrm{K}_{100}$ & $12.00 \mathrm{ab}$ & $2.36 \mathrm{~b}$ & $2.33 \mathrm{ab}$ & $27.88 \mathrm{~b}$ & $16.38 \mathrm{~b}$ & $11.70 \mathrm{a}$ \\
\hline $\mathrm{NaCl}_{180}$ & $6.60 \mathrm{~d}$ & $1.83 \mathrm{c}$ & $1.71 \mathrm{~d}$ & $11.18 \mathrm{~d}$ & $7.08 \mathrm{~d}$ & $4.10 \mathrm{~d}$ \\
\hline $\mathrm{NaCl}_{180}+\mathrm{K}_{50}$ & $9.00 \mathrm{~cd}$ & $2.11 b c$ & $2.01 \mathrm{c}$ & $18.11 \mathrm{~cd}$ & $10.93 \mathrm{~cd}$ & $7.18 \mathrm{c}$ \\
\hline $\mathrm{NaCl}_{180}+\mathrm{K}_{100}$ & $10.60 \mathrm{bc}$ & $2.30 \mathrm{~b}$ & $2.23 a b c$ & $23.57 \mathrm{bc}$ & $13.89 \mathrm{bc}$ & $9.68 \mathrm{ab}$ \\
\hline
\end{tabular}

Table 3: Fiber quality characteristics of cotton (Gossypium hirsutum L.) grown under NaCl stress by supplying $\mathrm{K}$

\begin{tabular}{lllll}
\hline Treatments & $\begin{array}{l}\text { Ginning out turn } \\
(\%)\end{array}$ & $\begin{array}{l}\text { Staple length } \\
(\mathbf{m m})\end{array}$ & $\begin{array}{l}\text { Fiber strength } \\
(\mathbf{g} / \text { tex })\end{array}$ & $\begin{array}{l}\text { Fiber fineness } \\
\text { (Micronaire value) }\end{array}$ \\
\hline $\mathrm{Control}$ & $43.61 \mathrm{a}$ & $28.78 \mathrm{a}$ & $98.40 \mathrm{a}$ & $4.76 \mathrm{a}$ \\
$\mathrm{NaCl}_{100}$ & $38.76 \mathrm{bc}$ & $26.24 \mathrm{~cd}$ & $92.00 \mathrm{bcd}$ & $3.62 \mathrm{~cd}$ \\
$\mathrm{NaCl}_{100}+\mathrm{K}_{50}$ & $41.35 \mathrm{ab}$ & $27.22 \mathrm{bc}$ & $95.24 \mathrm{ab}$ & $4.06 \mathrm{bc}$ \\
$\mathrm{NaCl}_{100}+\mathrm{K}_{100}$ & $42.02 \mathrm{ab}$ & $28.06 \mathrm{ab}$ & $95.82 \mathrm{ab}$ & $4.34 \mathrm{ab}$ \\
$\mathrm{NaCl}_{180}$ & $36.68 \mathrm{c}$ & $25.46 \mathrm{~d}$ & $87.96 \mathrm{~d}$ & $3.00 \mathrm{e}$ \\
$\mathrm{NaCl}_{180}+\mathrm{K}_{50}$ & $39.62 \mathrm{bc}$ & $26.48 \mathrm{~cd}$ & $90.60 \mathrm{~cd}$ & $3.48 \mathrm{~d}$ \\
$\mathrm{NaCl}_{180}+\mathrm{K}_{100}$ & $41.01 \mathrm{ab}$ & $27.30 \mathrm{bc}$ & $92.32 \mathrm{bc}$ & $3.92 \mathrm{bcd}$ \\
\hline
\end{tabular}

Control: no NaCl, no additional K, NaCl $100: 100 \mathrm{mM} \mathrm{NaCl}, \mathrm{NaCl}_{100}+\mathrm{K}_{50}: 100 \mathrm{mM} \mathrm{NaCl}+50 \mathrm{mg} \mathrm{K}_{2} \mathrm{O} \mathrm{kg}^{-1}$ soil, $\mathrm{NaCl}_{100}+\mathrm{K}_{100}: 100 \mathrm{mM}$ $\mathrm{NaCl}+100 \mathrm{mg} \mathrm{K}_{2} \mathrm{O} \mathrm{kg}^{-1}$ soil, $\mathrm{NaCl}_{180}: 180 \mathrm{mM} \mathrm{NaCl}, \mathrm{NaCl}_{180}+\mathrm{K}_{50}$ : $180 \mathrm{mM} \mathrm{NaCl}+50 \mathrm{mg} \mathrm{K}_{2} \mathrm{O} \mathrm{kg}^{-1}$ soil, $\mathrm{NaCl}_{180}+\mathrm{K}_{100}$ : $180 \mathrm{mM}$ $\mathrm{NaCl}+100 \mathrm{mg} \mathrm{K}_{2} \mathrm{O} \mathrm{kg}^{-1}$ soil.

improved both of these characteristics at both $\mathrm{NaCl}$ levels. However, alleviative effect of $\mathrm{K}$ was relatively more at higher K level. Seed weight per plant was decreased by $52.59 \%$ at $\mathrm{NaCl}_{100}$ and $70.84 \%$ at $\mathrm{NaCl}_{180}$ compared to control. K nutrition improved the seed weight per plant by 24.76 and $42.31 \%$ at $\mathrm{NaCl}_{100}$ while 54.38 and $96.18 \%$ at $\mathrm{NaCl}_{180}$ with $\mathrm{K}_{50}$ and $\mathrm{K}_{100}$, respectively compared to $\mathrm{NaCl}$ treated plants without additional $\mathrm{K}$. Maximum seed cotton weight per plant was found in control which was reduced by $47.47 \%$ at $\mathrm{NaCl}_{100}$ and $68.76 \%$ at $\mathrm{NaCl}_{180}$. Additional $\mathrm{K}$ improved seed cotton weight per plant by 29.68 and $48.30 \%$ at $\mathrm{NaCl}_{100}$ while 61.98 and $111 \%$ at $\mathrm{NaCl}_{180}$ with $\mathrm{K}_{50}$ and $\mathrm{K}_{100}$, respectively compared to control. Lint yield per plant was declined by $36.66 \%$ at $\mathrm{NaCl}_{100}$ and $64.37 \%$ at $\mathrm{NaCl}_{180}$ compared to control. $\mathrm{K}$ nutrition alleviated the adverse effects of $\mathrm{NaCl}$ on plant growth and development and improved lint yield by 38.27 and $60.49 \%$ at $\mathrm{NaCl}_{100}$ while 75.12 and $136 \%$ at $\mathrm{NaCl}_{180}$ with $\mathrm{K}_{50}$ and $\mathrm{K}_{100}$, respectively compared to $\mathrm{NaCl}$ treated plants without additional $\mathrm{K}$.

\section{Fiber quality characteristics}

Results presented in Table 3 revealed that fiber quality characteristics were significantly $(\mathrm{P} \leq 0.05)$ affected by different levels of $\mathrm{NaCl}$ and additional K. Ginning out-turn was decreased by 11.12 and $15.89 \%$ by $\mathrm{NaCl}_{100}$ and
$\mathrm{NaCl}_{180}$, respectively compared to control. $\mathrm{K}$ nutrition in saline environment improved ginning out-turn by 6.68 and $8.41 \%$ at $\mathrm{NaCl}_{100}$ while 8.01 and $11.80 \%$ at $\mathrm{NaCl}_{180}$ with $\mathrm{K}_{50}$ and $\mathrm{K}_{100}$, respectively compared to $\mathrm{NaCl}$ treated plants without additional K. Staple length, fiber strength and fiber fineness were also decreased linearly by increasing $\mathrm{NaCl}$ concentration in the growth medium. Application of additional $\mathrm{K}$ at both levels of $\mathrm{NaCl}$ reversed the adverse effects of $\mathrm{NaCl}$ and improved the fiber quality characteristics. It was interesting that adverse effects of $\mathrm{NaCl}$ and ameliorative effect of additional $\mathrm{K}$ on fiber quality was relatively small when compared with growth and yield characteristics of cotton at both levels of $\mathrm{NaCl}$ and $\mathrm{K}$.

\section{Discussion}

Understanding the salinity-nutrients relationships is of great economic importance because nutrients could provide protective mechanisms against salinity stress by reducing ion toxicity through competitive ion uptake and dilution effect, maintaining ionic balance, contribution to osmotic adjustment and scavenging of reactive oxygen species under saline conditions (Marschner, 1995). In present study, $\mathrm{NaCl}$ caused a marked increase in shoot $\mathrm{Na}^{+}$and $\mathrm{Cl}^{-}$while decrease in $\mathrm{Ca}^{2+}, \mathrm{Mg}^{2+}, \mathrm{K}^{+}$and $\mathrm{K}^{+}: \mathrm{Na}^{+}$ratio in cotton grown at $\mathrm{NaCl}_{100}$ and $\mathrm{NaCl}_{180}$ compared to control. The 
major mechanisms of salt effects on ion uptake and accumulation within plant were the ion antagonism, reduction in water availability and absorption, disruption of root membrane integrity and reduction in relative growth rate that resulting in a lower nutrient demand. Chen et al. (2010) demonstrated that $\mathrm{Na}^{+}$uptake was increased with increasing salinity and the displacement of $\mathrm{K}^{+} / \mathrm{Ca}^{2+}$ by $\mathrm{Na}^{+}$ under salt stress could cause nutritional imbalances. Ashraf et al. (2015b) also observed that increasing $\mathrm{NaCl}$ concentration in the growth medium enhanced the uptake of $\mathrm{Na}^{+}$while decreased $\mathrm{K}^{+}$, showing an apparent antagonism between $\mathrm{Na}^{+}$and $\mathrm{K}^{+}$in sunflower. Therefore, plant's capabilities to endure salt stress could be related to its ability for limiting $\mathrm{Na}^{+}$uptake and/or transport from roots to shoots, and increasing $\mathrm{K}^{+}$content (Siringam et al., 2011). Exogenous application of $\mathrm{K}$ at both levels reduced $\mathrm{Na}^{+}$ accumulation, increased $\mathrm{Ca}^{2+}, \mathrm{K}^{+}$concentration and $\mathrm{K}^{+}: \mathrm{Na}^{+}$ ratio, all these played an important role in improving plant tolerance to salinity. Alleviative effect of added $\mathrm{K}$ in reversing the adverse effects of $\mathrm{NaCl}$ was relatively more prominent at higher K level. Ashraf et al. (2015a) found that $\mathrm{K}$ addition to saline environment increased $\mathrm{K}^{+}$and $\mathrm{K}^{+}$: $\mathrm{Na}^{+}$ratio which were subsequently responsible for enhanced salt tolerance in sugarcane.

Reduction in RWC under $\mathrm{NaCl}$ stress might be attributed to salt-induced reduction in water potential in the root zone which inhibited the plant's ability to extract water from soil and transport to aerial plant parts. Ashraf et al. (2015b) reported that salinity stress caused a marked decrease in RWC in sunflower. Additional K improved RWC through its direct involvement in osmotic adjustment or by improving $\mathrm{Ca}^{2+}$ accumulation under salinity stress. Cakmak (2005) also reported $\mathrm{K}$ contribution to water economy under salt stress. $\mathrm{NaCl}$-induced reduction in MSI was attributed to displacement of $\mathrm{Ca}^{2+}$ by $\mathrm{Na}^{+}$from membrane structure which caused disorganization of membrane structure and decreased MSI. Potassium nutrition under salinity stress improved $\mathrm{Ca}^{2+}$ uptake and accumulation, and increased MSI. In addition, $\mathrm{K}$ could also improve MSI through its protective role against oxidative stress in saline environment. These findings were in accordance with Cakmak (2002; 2005); Gunes et al. (2007); Ashraf et al. (2015b).

Inhibition in plant growth, yield and yield attributes of cotton including plant height, boll number plant ${ }^{-1}$, boll diameter, seed cotton weight boll ${ }^{-1}$, seed cotton weight plant $^{-1}$, seed weight plant ${ }^{-1}$ and lint yield plant ${ }^{-1}$ at both levels of $\mathrm{NaCl}$ was attributed to ion toxicity, reduced RWC, MSI and disturbed ionic balance. In saline environment, salt ions strongly competed with essential mineral nutrients, particularly $\mathrm{Ca}^{2+}$ and $\mathrm{K}^{+}$resulting in their reduced uptake and accumulation. Consequently, excess of $\mathrm{Na}^{+}$and $\mathrm{Cl}^{-}$or deficiency of $\mathrm{K}^{+}, \mathrm{Ca}^{2+}$ and $\mathrm{Mg}^{2+}$ or any other essential nutrient disturbed growth processes and causing severe decline in plant growth and yield (Ashraf et al., 2015a). Furthermore, salinity-induced reduction in water and $\mathrm{K}^{+}$ uptake by plants usually interfered with cell division and/or extension because of reduced turgor, leading to reduced plant growth and development (Ashraf et al., 2008). Addition of plant mineral nutrients through soil or foliar spray could provide protective mechanisms against salinity stress (Kaya et al., 2007; Murillo-Amador et al., 2007; Ashraf et al., 2012; Ashraf et al., 2015b). It was found that application of additional $\mathrm{K}\left(\mathrm{K}_{50}\right.$ and $\left.\mathrm{K}_{100}\right)$ to salt-stressed medium $\left(\mathrm{NaCl}_{100}\right.$ and $\left.\mathrm{NaCl}_{180}\right)$ reduced the uptake of $\mathrm{Na}^{+}$ and $\mathrm{Cl}^{-}$, and improved cotton growth and yield. Lint yield plant $^{-1}$ was positively correlated with shoot $\mathrm{K}^{+}$ concentration $\left(R^{2}=0.702\right.$, Fig. 6$)$.

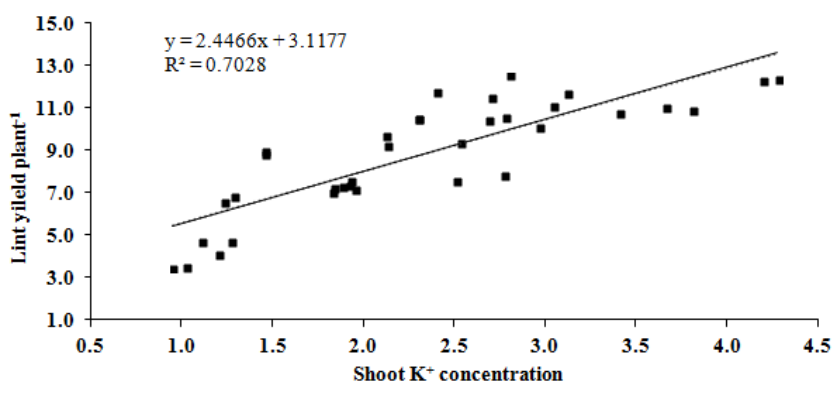

Fig. 6: Correlation between shoot $\mathrm{K}^{+}$concentration and lint yield plant $^{-1}$ in cotton grown under $\mathrm{NaCl}$ stress by supplying $K$

These findings were contradicted to earlier research which reported that higher $\mathrm{K}$ application in saline environment hastened the deleterious impacts of salinity on plant growth causing severe decline in plant growth and development in sorghum (Sorghum bicolor L.) under salt stress (Jafari et al., 2009).

Decline in fiber quality characteristics including ginning out-turn, staple length, fiber strength and fiber fineness of cotton at both levels of $\mathrm{NaCl}$ was mainly attributed to antagonistic effects of $\mathrm{Na}^{+}$with $\mathrm{K}^{+}$and $\mathrm{Ca}^{2+}$ accumulation by plant under salinity stress. During the formation and development of fruit, $\mathrm{K}^{+}$and $\mathrm{Ca}^{2+}$ are required for carbohydrate metabolism and transfer of metabolites from leaves to developing bolls. Salinity-induced $\mathrm{K}^{+}$and $\mathrm{Ca}^{2+}$ deficiency, particularly during reproductive phase could damage the fruit organs, decreased seed cotton yield and fiber quality. Sawan (2014) demonstrated that $\mathrm{K}^{+}$and $\mathrm{Ca}^{2+}$ deficiency affected boll structure and caused abscission of young bolls, and consequently reduced seed cotton yield and quality. Potassium nutrition at both levels of $\mathrm{NaCl}$ alleviated the adverse effects of $\mathrm{Na}^{+}$and improved fiber quality characteristics. Some past studies, for example Gormus (2002); Aneela et al. (2003); Pervez et al. (2004); 
Pettigrew et al. (2005); Sharma and Sundar (2007) also reported an improvement in cotton growth, lint yield and fiber quality by $\mathrm{K}$ nutrition.

\section{Conclusion}

External $\mathrm{NaCl}$ markedly increased shoot $\mathrm{Na}^{+}$and $\mathrm{Cl}^{-}$ while decreased $\mathrm{K}^{+}, \mathrm{K}^{+}: \mathrm{Na}^{+}$ratio, $\mathrm{Ca}^{2+}, \mathrm{Mg}^{2+}$, RWC and MSI with a subsequent decline in yield and yield attributes as well as fiber quality characteristics. Potassium nutrition at both levels of $\mathrm{NaCl}$ stress interfered with $\mathrm{Na}^{+}$, reduced its accumulation with a corresponding increase in shoot $\mathrm{K}^{+}$, $\mathrm{K}^{+}: \mathrm{Na}^{+}$ratio and $\mathrm{Ca}^{2+}$, and ultimately reversed the damaging effects of $\mathrm{NaCl}$ on yield attributes and fiber quality. The protective role of $\mathrm{K}$ in cotton plants suffering from salinity stress has been attributed to maintenance of lower $\mathrm{Na}^{+}$, higher $\mathrm{Ca}^{2+}, \mathrm{K}^{+}$, and $\mathrm{K}^{+} ; \mathrm{Na}^{+}$ratio accompanied by greater RWC and MSI.

\section{References}

Aneela, S., A. Muhammad and M.E. Akhtar. 2003. Effect of potash on boll characteristics and seed cotton yield in newly developed highly resistant cotton varieties. Pakistan Journal of Biological Sciences 6: 813-815.

Arzani, A. 2008. Improving salinity tolerance in crop plants: A biotechnological view. In Vitro Cellular \& Developmental Biology - Plant 44: 373-383.

Ashraf, M. 2002. Salt tolerance of cotton: some new advances. Critical Reviews in Plant Sciences 21: 1-30.

Ashraf, M., M. Abid, J.A. Teixeira da Silva, S.M. Shahzad, A. Hussain and M. Imtiaz. 2015b. Silicon and potassium nutrition enhances salt adaptation capability of sunflower by improving plant water status and membrane stability. Communication in Soil Science and Plant Analysis 46: 991-1005.

Ashraf, M., M. Afzal, R. Ahmed, M.A. Maqsood, S.M. Shahzad, M.A. Tahir, N. Akhtar and A. Aziz. 2012. Growth response of salt-sensitive and salt-tolerant sugarcane genotypes to potassium nutrition under salt stress. Archives of Agronomy and Soil Science 58: 385398.

Ashraf, M., Rahmatullah, R. Ahmad, A.S. Bhatti, A. Sarwar, M.A. Maqsood and S. Kanwal. 2010. Alleviation of salt stress in sugarcane (Saccharum officinarum L.) by supplying potassium and silicon in hydroponics. Pedosphere 20: 153-162.

Ashraf, M., S.M. Shahzad, M.S. Arif, M. Abid, M. Riaz and S. Ali. 2015a. Effects of potassium sulfate on adaptability of sugarcane cultivars to salt stress under hydroponic conditions. Journal of Plant Nutrition 38: 2126-2138.

Ashraf, M.Y., F. Hussain, J. Akhter, A. Gul, M. Ross and G. Ebert. 2008. Effect of different sources and rates of nitrogen and supra optimal level of potassium fertilization on growth, yield and nutrient uptake by sugarcane grown under saline conditions. Pakistan Journal of Botany 40: 1521-1531.

ASTM (American Society for Testing and Materials). 1994a. Standard test method for fiber length and length distribution of cotton fibers. ASTM Standard D 533292. 07.02:753-756. Annual Book of ASTM Standards. ASTM, Philadelphia, PA.

ASTM (American Society for Testing and Materials). 1994b. Standard test methods for measurement of cotton fibers by high volume instruments (HVI). ASTM Standard D 4604-86. 7.02:475-485; ASTM Standard D 4605-86. 7.02:486-494. Annual Book of ASTM Standards. ASTM, Philadelphia, PA.

ASTM (American Society for Testing and Materials). 1994c. Standard test method for breaking strength and elongation of fibers (Flat bundle method). ASTM Standard D 1445-90. 07.01:392-397. Annual Book of ASTM Standards. ASTM, Philadelphia, PA.

Cakmak, I. 2002. Plant nutrition research: Priorities to meet human needs for food in sustainable ways. Plant and Soil 247: 3-24.

Cakmak, I. 2005. The role of potassium in alleviating detrimental effects of abiotic stresses in plants. Journal of Plant Nutrition and Soil Science 168: 521-530.

Cassman, K.G., B.A. Roberts, T.A. Kerby, D.C. Bryant and D.C. Higashi. 1989. Soil potassium balance and cumulative cotton response to annual potassium additions on a vermiculitic soil. Soil Science Society of America Journal 53: 805-812.

Chen, W., Z, Hou, L. Wu, Y. Liang and C. Wei. 2010. Effects of salinity and nitrogen on cotton growth in arid environment. Plant and Soil 326: 61-73.

Ghogdi, E.A., A. Izadi-Darbandi and A. Borzouei. 2012. Effects of salinity on some physiological traits in wheat (Triticum aestivum L.) cultivars. Indian Journal Science and Technology 5: 1901-1906.

Gormus, O. 2002. Effects of rate and time of potassium application on cotton yield and quality in Turkey. Journal of Agronomy and Crop Science 188: 382-388.

Gunes, A., A. Inal and E.G. Bagci. 2007. Silicon-mediated changes of some physiological and enzymatic parameters symptomatic for oxidative stress in spinach and tomato grown in sodic-B toxic soil. Plant and Soil 290: 103-114.

Jafri, A.Z. and R. Ahmad. 1994. Plant growth and ionic distribution in cotton under saline environment. Pakistan Journal of Botany 26: 105-114.

Jamil, M., T. Charnikhova, C. Cardoso, T. Jamil, F. Verstappen and H. Bouwmeester. 2011. Quantification of the relationship between strigolactones and Striga 
hermonthica in rice under varying levels of nitrogen and phosphorus. Weed Research 51: 373-385.

Kaya, C., A.L. Tuna, M. Ashraf and H. Altunlu. 2007. Improved salt tolerance of melon (Cucumis melo L.) by the addition of proline and potassium nitrate. Environmental and Experimental Botany 60: 397-403.

Khorsandi F. and A. Anagholi. 2009. Reproductive compensation of cotton after salt stress relief at different growth stages. Journal of Agronomy Crop Science 195: 278-283.

Maas, E.V. 1986. Salt tolerance of plants. Applied Agricultural Research 1: 12-26.

Marschner, H. 1995. Mineral Nutrition of Higher Plants. $2^{\text {nd }}$ ed., Academic Press, San Diego, London. Edited by Bacon, P.E. and M. Dekker, New York, USA, p 889.

Mengel, K. and E.A. Kirkby. 2001. Principles of Plant Nutrition. $5^{\text {th }}$ ed., Kluwer Academic Publishers, Dordrecht, p 849.

Murillo-Amador, B., S. Yamada, T. Yamaguchi, E. RuedaPuente, N. Avila-Serrano, J. L. Garcia-Hernandez, R. Lopez-Aguilar, E. Troyo-Dieguez and A. NietoGaribay. 2007. Influence of calcium silicate on growth, physiological parameters and mineral nutrition in two legume species under salt stress. Journal of Agronomy and Crop Science 193: 413-421.

Pervez, H., M. Ashraf and M.I. Makhdum. 2004. Influence of potassium rates and sources on seed cotton yield and yield components of some elite cotton cultivars. Journal of Plant Nutrition 27: 1295-1317.

Pettigrew, W.T., W.R. Meredith Jr. and L.D. Young. 2005. Potassium fertilization effects on cotton lint yield, yield components, and reniform nematode populations. Agronomy Journal 97: 1245-1251.

Sairam, R.K. and A. Tyagi. 2004. Physiology and molecular biology of salinity stress tolerance in plants. Current Science 86: 407-421.

Jafari, M.H.S., M. Kafi and A. Astaraie. 2009. Interactive effects of $\mathrm{Nacl}$ induced salinity,calcium and potassium on physiomorphological.Traits of sorghum

Sairam, R.K., P.S. Deshmukh and D.S. Shukla. 1997. Increased antioxidant enzyme activity in response to drought and temperature stress related with stress tolerance in wheat genotypes. Abstract: National Seminar (ISSP), IARI, New Delhi, p 69.

Sawan, Z.M. 2014. Cottonseed yield and its quality as affected by mineral fertilizers and plant growth retardants. Agricultural Science 5: 186-209.

Sharma, S.K. and S. Sundar. 2007. Yield, yield attributes and quality of cotton as influenced by foliar application of potassium. Journal of Cotton Research and Development 21: 51-54.

Shirazi, M.U., M.Y. Ashraf, M.A. Khan and M.H. Naqvi. 2005. Potassium induced salinity tolerance in wheat (Triticum aestivum L.). International Journal of Environmental Sciences 2: 233-236.

Siringam, K., N. Juntawong, S. Cha-Um and C. Kirdmanee. 2011. Salt stress induced ion accumulation, ion homeostasis, membrane injury and sugar contents in salt-sensitive rice (Oryza sativa L. spp. indica) roots under iso-osmotic conditions. African Journal of Biotechnology 10: 1340-1346.

Waraich, E.A., R. Ahmad, M.Y. Ashraf and Ehsanullah. 2011. Role of mineral nutrition in alleviation of drought stress in plants. Australian Journal of Crop Science 5: 764-777.

Win, K.T., A.Z. Oo, T. Hirasawa, T. Ookawa and H. Yutaka. 2011. Genetic analysis of Myanmar Vigna species in responses to salt stress at the seedling stage. African Journal of Biotechnology 10: 1615-1624.

Yamasaki, S. and L.R. Dillenburg. 1999. Measurements of leaf relative water content in Araucaria angustifolia. Revista Brasilleira de Fisiologia Vegetal 11: 69-75.

Zhang, L., H. Ma, T. Chen, J. Pen, S. Yu and X. Zhao. 2014. Morphological and physiological responses of cotton (Gossypium hirsutum L.) plants to salinity. PLoS ONE, 9: Doi: 10.1371/ journal.pone.0112807 